\title{
Growth of magnetotactic sulfate-reducing bacteria in oxygen concentration gradient medium
}

\author{
Christopher T. Lefèvre, ${ }^{1 *}$ Paul A. Howse, ${ }^{2}$ \\ Marian L. Schmidt, ${ }^{3}$ Monique Sabaty, ${ }^{1}$ \\ Nicolas Menguy, ${ }^{4}$ George W. Luther ${ }^{1 I{ }^{5}}$ and \\ Dennis A. Bazylinski ${ }^{2 * *}$ \\ ${ }^{1}$ CNRS/CEA/Aix-Marseille Université UMR7265 Institut \\ de biosciences et biotechnologies Laboratoire de \\ Bioénergétique Cellulaire, Saint Paul lez Durance, \\ 13108, France. \\ ${ }^{2}$ School of Life Sciences, University of Nevada at Las \\ Vegas, Las Vegas, NV, 89154-4004, USA. \\ ${ }^{3}$ Department of Ecology and Evolutionary Biology, \\ University of Michigan, Ann Arbor, MI, USA. \\ ${ }^{4}$ Institut de Minéralogie, de Physique des Matériaux et \\ de Cosmochimie, Sorbonne Universités, Université \\ Pierre et Marie Curie, UMR 7590 CNRS, Institut de \\ Recherche pour le Développement UMR 206, Museum \\ National d'Histoire Naturelle, Paris Cedex 05, 75252, \\ France. \\ ${ }^{5}$ School of Marine Science and Policy, University of \\ Delaware, 700 Pilottown Rd. Lewes, DE, 19958, USA
}

\section{Summary}

Although dissimilatory sulfate-reducing bacteria (SRB) are generally described as strictly anaerobic organisms with regard to growth, several reports have shown that some SRB, particularly Desulfovibrio species, are quite resistant to $\mathrm{O}_{2}$. For example, SRB remain viable in many aerobic environments while some even reduce $\mathrm{O}_{2}$ to $\mathrm{H}_{2} \mathrm{O}$. However, reproducible aerobic growth of SRB has not been unequivocally documented. Desulfovibrio magneticus is a SRB that is also a magnetotactic bacterium (MTB). MTB biomineralize magnetosomes which are intracellular, membrane-bounded, magnetic iron mineral crystals. The ability of $D$. magneticus to grow aerobically in several different media under air where an $\mathrm{O}_{2}$ concentration gradient formed, or under $\mathrm{O}_{2}$-free $\mathrm{N}_{2}$ gas was tested. Under air, cells grew as a microaerophilic band of cells at the oxic-anoxic interface in media lacking sulfate. These results show that

\footnotetext{
*For correspondence. ${ }^{*}$ E-mail christopher.lefevre @ cea.fr; Tel. +33 4422532 93. **E-mail dennis.bazylinski@unlv.edu; Tel. +01-702-895-5832; Fax +01702 8953956 .
}

D. magneticus is capable of aerobic growth with $\mathrm{O}_{2}$ as a terminal electron acceptor. This is the first report of consistent, reproducible aerobic growth of SRB. This finding is critical in determining important ecological roles SRB play in the environment. Interestingly, the crystal structure of the magnetite crystals of $D$. magneticus grown under microaerobic conditions showed significant differences compared with those produced anaerobically providing more evidence that environmental parameters influence magnetosome formation.

\section{Introduction}

Dissimilatory sulfate-reducing bacteria (SRB) are generally considered to be strict anaerobes regarding growth (Rabus et al., 2013). Widespread in marine and freshwater sediments, they constitute a morphologically and metabolically diverse group of prokaryotes, phylogenetically belonging to both the Bacteria and Archaea domains, and able to use a wide variety of organic compounds. SRB obtain energy for cell synthesis and growth by coupling the oxidation of these organic compounds or molecular hydrogen $\left(\mathrm{H}_{2}\right)$ to the reduction of sulfate $\left(\mathrm{SO}_{4}^{2-}\right)$ to sulfide $\left(\mathrm{H}_{2} \mathrm{~S}, \mathrm{HS}^{-}\right)$(Rabus et al., 2013).

Most known SRB belong to the Deltaproteobacteria class of the Proteobacteria phylum in the domain Bacteria. Those in the genus Desulfovibrio were described as strictly anaerobic bacteria since their discovery more than 100 years ago (Beijerinck, 1895). D. vulgaris and $D$. desulfuricans were used for many years as model organisms to study sulfate reduction (Voordouw and Wall, 1993). Dissimilatory SRB are often present in biotopes where they are exposed to oxic conditions and some have even been shown to be metabolically active in microaerobic environments (Hardy and Hamilton, 1981; Battersby et al., 1985; Sass et al., 1996; 1997; Krekeler et al., 1997; Sass et al., 1998; Lobo et al., 2007) showing that these bacteria are quite resistant to $\mathrm{O}_{2}$ (Cypionka et al., 1985; Sass et al., 1996; 1997; 1998; Krekeler et al., 1997). Some SRB not only survive exposure to $\mathrm{O}_{2}$ for at least days, but some even reduce $\mathrm{O}_{2}$ to $\mathrm{H}_{2} \mathrm{O}$ (Dannenberg et al., 1992), coupling aerobic respiration to ATP formation (Dilling and Cypionka, 1990; 
Cypionka, 2000) driving $\mathrm{O}_{2}$-dependent enhancement of growth (Sigalevich et al., 2000). Johnson et al. reported aerobic growth of $D$. vulgaris Hildenborough although growth was meagre at best if even present (Johnson et al., 1997).

To counteract the deleterious effects of highly reactive derivatives of $\mathrm{O}_{2}$, many anaerobic organisms developed defense systems similar to those found in aerobes (Storz et al., 1990; Dolla et al., 2006). Despite the capacity of some SRB to couple $\mathrm{O}_{2}$ reduction with energy conservation, the observed chemotaxis of some species toward microaerobic zones, and the detoxification mechanisms developed by some strains, consistent, reproducible aerobic growth by SRB for an infinite number of generations has never been observed (Cypionka, 2000; Dolla et al., 2006; Rabus et al., 2013). Other alternative terminal electron acceptors to sulfate are used by some SRB; for instance, inorganic sulfur species such as sulfite $\left(\mathrm{SO}_{3}^{2-}\right)$, thiosulfate $\left(\mathrm{S}_{2} \mathrm{O}_{3}^{2-}\right)$, trithionate $\left(\mathrm{S}_{3} \mathrm{O}_{6}^{2-}\right)$, tetrathionate $\left(\mathrm{S}_{4} \mathrm{O}_{6}^{2-}\right)$ and dithionite $\left(\mathrm{S}_{2} \mathrm{O}_{4}^{2-}\right)$ are respired by some Desulfovibrio species while sulfonates, dimethyl sulfoxide (DMSO), nitrate and nitrite are also used by some SRB. Fumarate and malate are also fermented by some Desulfovibrio species (Rabus et al., 2013). Thus there is no reason to assume that the capacities for dissimilatory sulfate reduction and aerobic growth in the same bacterium are mutually exclusive.

Magnetotactic bacteria (MTB) biomineralize magnetosomes, intracellular membrane-enclosed magnetic crystals, causing them to swim along the Earth's geomagnetic field lines. MTB are ubiquitous in aquatic environments but are generally localized at the oxicanoxic interface (OAl) (Bazylinski and Frankel, 2004). Magnetosomes appear to enhance aerotaxis by reducing a 3-dimensional search for the OAl to 1-dimension where cells swim up and down along the Earth's inclined geomagnetic field lines (Bazylinski and Frankel, 2004). MTB belong to three major groups of Gram-negative prokaryotes including the Proteobacteria, Nitrospirae and Omnitrophica phyla (Bazylinski et al., 2013) and possibly the candidate phylum Latescibacteria (Lin and Pan, 2015) of the Fibrobacteres-Chlorobi-Bacteroidetes (FCB) superphylum (Rinke et al., 2013). Deltaproteobacterial MTB reduce and grow with sulfate as a terminal electron acceptor (Bazylinski et al., 2013). The polyphyletic origin idea of magnetosome biomineralization arose from the discovery of the first magnetotactic Deltaproteobacteria, a multicellular magnetotactic prokaryote (DeLong et al., 1993), later found to likely be a SRB (Abreu et al., 2011). Other deltaproteobacterial sulfatereducing MTB have been isolated and described (Lefèvre and Bazylinski, 2013).

Magnetosome crystals have high chemical purity, narrow size ranges, species-specific crystal morphologies and exhibit specific arrangements within the cell. These features indicate that the formation of magnetosomes by MTB is under precise biological control. Phylogenetic analysis shows that there is an important correlation between the composition and morphology of the magnetosome mineral crystals produced by MTB and their phylogenetic affiliation (Abreu et al., 2011; Lefèvre et al., 2011a,b, 2012, 2013). Magnetotactic Alpha- and Gammaproteobacteria, the later-diverging classes of the Proteobacteria, biomineralize morphologically consistent, well-defined crystals of magnetite that include cuboctahedral and elongated prisms (Devouard et al., 1998; Lefèvre et al., 2012). In contrast, in the magnetotactic Deltaproteobacteria, the most deeply diverging group of the Proteobacteria, that biomineralize magnetite, greigite, or both, the magnetite crystals are always bulletshaped. The magnetotactic Nitrospirae and Omnitrophica, the more deeply branching phylogenetic groups that contain MTB (Jogler et al., 2011; Kolinko et al., 2012), are known to biomineralize only magnetite crystals whose morphologies are very similar to those found in the Deltaproteobacteria (Lefèvre et al., 2011a, b). Thus, based on the phylogeny of MTB and the type of magnetosomes that they biomineralize, it has been suggested that bullet-shaped magnetite crystals represent the first magnetosome mineral phase (Lefèvre et al., 2013). In addition to the genetic control over the type of crystal mineralized in the magnetosome membrane, environmental parameters also play a role in the regulation of magnetosome formation. For instance, it was shown that rates of iron uptake change the morphology of magnetite crystals (Faivre et al., 2008). Culturing experiments also showed that depending on environmental conditions, strain BW-1, preferentially mineralizes magnetite (high redox potential) or greigite (reduced conditions) as a function of the redox conditions (Lefèvre et al., 2011a, b).

Here we show that some magnetotactic SRB of the genus Desulfovibrio are capable of reproducible, consistent aerobic growth in semi-solid oxygen concentration gradient ( $\left[\mathrm{O}_{2}\right]$-gradient) medium lacking sulfate. In such conditions, the magnetosomes present consistent morphological variations that could be used as biomarkers to understand past environmental conditions present in geological records where such magnetosome morphology was deposited.

\section{Results}

\section{Isolation of magnetotactic SRB}

MTB were magnetically concentrated and purified from samples from different freshwater environments (Bazylinski et al., 2013) and used as inocula into semi-solid, $\left[\mathrm{O}_{2}\right]$-gradient growth medium containing succinate as 


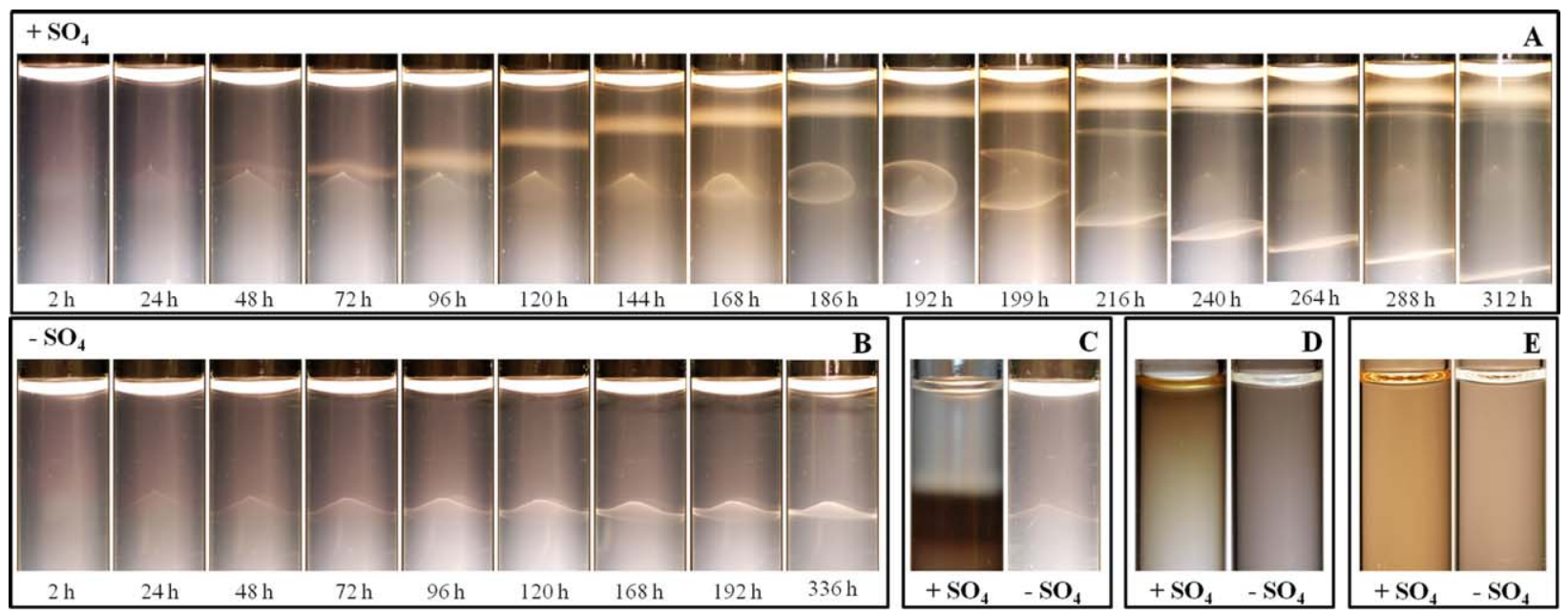

Fig. 1. Growth of Desulfovibrio magneticus strain RS-1 in $\left[\mathrm{O}_{2}\right]$-gradient medium in the presence or absence of sulfate. (A) Semi-solid $\left[\mathrm{O}_{2}\right]$-gradient medium containing $5.3 \mathrm{mM}$ sulfate. Here growth occurs initially as a microaerophilic band at the oxic-anoxic interface (OAI). After approximately $186 \mathrm{~h}$, the band splits into two, one migrating to the meniscus of the medium apparently seeking $\mathrm{O}_{2}$ in the microaerobic zone, the other migrating to the anaerobic zone of the tube apparently seeking sulfate. The thick white band, visible after $48 \mathrm{~h}$, is composed of elemental sulfur $\left(\mathrm{S}^{0}\right)$ formed by the interaction of $\mathrm{H}_{2} \mathrm{~S}$ and $\mathrm{O}_{2}$ (Supporting Information Fig. S2). (B) Semi-solid $\left[\mathrm{O}_{2}\right]$-gradient medium without sulfate (except for sulfate contamination in the salts used, determined to be $\sim 20 \mathrm{nM}$ ). Cells inoculated at the OAl spread and form a microaerophilic band after $24 \mathrm{~h}$. The size and thickness of the band increases while cells grow and stay at the OAl indicating that they are respiring and growing with $\mathrm{O}_{2}$ as the terminal electron acceptor. (C) Same growth conditions as (A) (left) and (B) (right) with addition of $100 \mu \mathrm{M}$ iron to trap $\mathrm{H}_{2} \mathrm{~S}$ as a black precipitate of FeS indicating that sulfate reduction was occurring. The tube on the right stays clear indicating that no $\mathrm{H}_{2} \mathrm{~S}$ is formed during growth without sulfate. (D) Same growth conditions as (A) (left) and (B) (right) except that the headspace of the tube was replaced with $\mathrm{O}_{2}$ free Ar. Without $\mathrm{O}_{2}$, the tube without sulfate (right) shows no growth; when sulfate is present (left), growth occurs as shown by the production of FeS (dark colour). (E) Anaerobic liquid culture under Ar. Growth occurs only when sulfate is present in the medium (left) as shown by the production of FeS (dark colour).

the electron donor. After 10-14 days of incubation at $25^{\circ} \mathrm{C}$, those tubes containing purified MTB from a fish hatchery pond in Montana and a pond near Zuma Beach, Los Angeles, California, displayed a defined band of cells growing at the OAI. Light microscopic examination of cells in these cultures showed that they were magnetotactic and helical to vibrioid in morphology. MTB from the cultures were diluted to extinction three successive times to obtain axenic cultures. The strains from the fish hatchery in Montana and the pond near Zuma Beach are designated as strains FH-1 and ZBP-1 respectively.

Phylogenetic analysis, based on 16S rRNA gene sequences of $\mathrm{FH}-1$ and $\mathrm{ZBP}-1$, showed that both strains belong to the genus Desulfovibrio. The sequence of strain $\mathrm{FH}-1$ showed $99.5 \%$ identity with Desulfovibrio magneticus strain RS-1 ${ }^{\top}$ (Sakaguchi et al., 2002) and strain ZBP-1 showed $99.5 \%$ identity with $D$. putealis strain B7-43 (Basso et al., 2005) (Supporting Information Fig. S1). Based on these high 16S rRNA gene sequence identities, $\mathrm{FH}-1$ and $\mathrm{ZBP}-1$ can be considered as strains of $D$. magneticus and $D$. putealis respectively. Cells of strains $\mathrm{FH}-1$ and ZBP-1 were repeatedly transferred in $\left[\mathrm{O}_{2}\right]$-gradient growth medium without sulfate and growth always occurred as a microaerophilic band of cells formed initially at the OAI. Growth of $D$. magneticus strain RS-1 was indistinguishable from that of strains $\mathrm{FH}-1$ and ZBP-1 in this medium. Because of the numerous studies on $D$. magneticus strain RS- 1 as well as its complete genome sequence available (Nakazawa et al., 2009), we focused our analyses on this strain. We have grown strain RS-1 consecutively since 2009 under microaerobic conditions in $\left[\mathrm{O}_{2}\right]$-gradient media lacking sulfate ( $>100$ transfers). This also applies for strains $\mathrm{FH}-1$ and ZBP-1.

When sulfate $(5.3 \mathrm{mM})$ was present in the growth medium, under an air headspace, initial growth of the strains was as a microaerophilic band of cells at the OAI (Fig. 1A). However, as the band thickened, cells appeared to reduce the sulfate to $\mathrm{H}_{2} \mathrm{~S}$ which accumulated and diffused toward the surface of the culture. $\mathrm{H}_{2} \mathrm{~S}$ then reacted with $\mathrm{O}_{2}$ resulting in a band of a sulfur-rich precipitate $\left(\mathrm{S}^{0}\right)$ a few millimeters above the microaerophilic band of cells (Supporting Information Fig. S2). As growth continued, the band split into two with an intermediate step where the cells form a ball-like appearance (Fig. 1A, 186 h). Cells in the upper band migrated toward the surface while those in the lower band migrated to the deeper part of the culture suggesting that those in the upper band were seeking $\mathrm{O}_{2}$ to respire while those in the lower band were seeking sulfate which was presumably depleted in the upper layers of the medium. When cells from the deeper band in $\left[\mathrm{O}_{2}\right]-$ gradient medium containing sulfate were transferred to 
the OAI of a tube of the same fresh medium, growth of the strains followed the same scheme as described above and in Fig. $1 \mathrm{~A}$.

In the same medium lacking sulfate (except for sulfate contamination in the salts used in the medium estimated at $20 \mathrm{nM}$ by liquid chromatography), cells still formed an initial band at the OAI but did not split in two. $\mathrm{H}_{2} \mathrm{~S}$ was not detected nor was a layer of $S^{0}$ indicating that sulfate reduction did not occur under these conditions (Fig. 1B). To confirm that sulfate reduction did not occur in medium lacking sulfate, the concentration of iron was raised to $100 \mu \mathrm{M}$ in order to detect and trap formed $\mathrm{H}_{2} \mathrm{~S}$ as FeS during sulfate reduction (Fig. 1C). In the presence of sulfate, cells produced $\mathrm{H}_{2} \mathrm{~S}$ and a black precipitate of FeS was observed, while in the absence of sulfate, no black precipitate was observed. To further demonstrate that $\mathrm{O}_{2}$ was required for growth in the absence of sulfate, we grew cells in the same medium with $\mathrm{O}_{2}$-free $\mathrm{N}_{2}$ in the headspace (Fig. 1D). In the absence of $\mathrm{O}_{2}$ and the presence of sulfate, cells grew while in the absence of sulfate no growth was observed. We also tested the growth in anaerobic liquid culture medium, with or without sulfate; growth only occurred when sulfate was present in the growth medium (Fig. 1E).

Molybdate has been shown to inhibit sulfate reduction in some SRB (Newport and Nedwell, 1988; Ranade et al., 1999). Indeed, molybdate is a structural analogue of sulfate which is thought to interact with key enzymes involved in sulfate reduction such as the ATP sulfurylase (Peck, 1959). The growth in the anaerobic liquid medium where cells of Desulfovibrio magneticus strain RS-1 reduce sulfate was inhibited by a concentration of sodium molybdate of $3 \mathrm{mM}$. When the same dose of molybdate was added to a semi-solid $\left[\mathrm{O}_{2}\right]$-gradient medium depleted with sulfate, the cells of strain RS- 1 continue to grow and to form a band at the OAI. In the same medium with sulfate, a band of cells also formed at the OAI while neither the band of cells in the anoxic zone nor the sulfur precipitates, usually observed in absence of molybdate (Fig. 1A), are formed in such conditions. This indicates that the cells in the band formed at the OAI, in presence or absence of sulfate, are using $\mathrm{O}_{2}$ as terminal electron acceptor.

\section{Additional evidence of aerobic respiration linked to growth in magnetotactic SRB}

A three microelectrode voltammetric probe was used to simultaneously determine $\mathrm{O}_{2}$ and $\mathrm{H}_{2} \mathrm{~S}$ concentration profiles (Brendel and Luther, 1995; Luther et al., 2008) (Fig. 2). The microaerophilic band observed in $\left[\mathrm{O}_{2}\right]$-gradient medium without sulfate formed at $\mathrm{O}_{2}$ concentration of about 28-31 $\mu \mathrm{M}$. The highest concentration ( 550 $\mu \mathrm{M}$ ) of $\mathrm{H}_{2} \mathrm{~S}$, only detected when sulfate was present in the medium, appeared at the depth of the second band of cells in the anaerobic zone. $\mathrm{H}_{2} \mathrm{~S}$ detected close to the upper microaerophilic band in the medium with sulfate likely results from upward diffusion of $\mathrm{H}_{2} \mathrm{~S}$ produced by the lower band. This diffusion would be expected even if the upper band was not present although the possibility that some sulfate reduction by cells in the upper band that become $\mathrm{O}_{2}$ starved cannot be excluded. When no sulfate was present in the medium, no $\mathrm{H}_{2} \mathrm{~S}$ was detected in the culture and only one band formed at the microaerophilic zone.

\section{$\mathrm{O}_{2}$ respiration rates of cells of strain $\mathrm{RS}-1$}

Cells of strain RS-1 grown anaerobically with fumarate completely consumed $\mathrm{O}_{2}$ (initial concentration $220 \mu \mathrm{M}$ ) in the chamber in the mass spectrometer within $15 \mathrm{~min}$ (Supporting Information Fig. S3). The $\mathrm{O}_{2}$ consumption rate measured on four independent suspensions was $128 \pm 27 \mathrm{nmol}$ of $\mathrm{O}_{2} \mathrm{~min}^{-1} \mathrm{mg}$ of protein ${ }^{-1}$.

\section{Growth under microaerobic conditions impacts cell and magnetosome morphologies}

Cells of $D$. magneticus strain $\mathrm{RS}-1$ grown in $\left[\mathrm{O}_{2}\right]$-gradient medium lacking sulfate were notably longer than cells grown on sulfate. The average size of the cells grown in the presence of sulfate was $2.3 \pm 0.7 \mu \mathrm{m}$ $(n=147)$ while the cells grown without sulfate had an average size of $4.8 \pm 2.0 \mu \mathrm{m}(n=147)$. Under all conditions tested, species of magnetotactic Desulfovibrio had a vibrioid to helical shape with one polar flagellum. Aggregate formation, which is one of the known mechanisms enabling some SRB to survive under periodic exposure to oxic conditions (Sigalevich et al., 2000), was occasionally observed in microaerophilic bands.

The number of magnetosomes per cell in RS-1 was higher in cells grown microaerobically with an average number of $15 \pm 6(n=25)$ while cells grown anaerobically with sulfate as electron acceptor had an average number of magnetosomes of $8 \pm 5(n=37)$. Interestingly, the size of the magnetite magnetosome crystals also varied depending upon culture conditions. While the width of the crystals appeared to be relatively constant $[30 \pm$ $6 \mathrm{~nm}(n=113)$ cells grown anaerobically with sulfate; $29 \pm 4 \mathrm{~nm}(n=258)$ cells grown microaerobically with $\mathrm{O}_{2}$ ], the length of the magnetosome crystals of cells grown under microaerobic conditions appeared to be longer $[57 \pm 16 \mathrm{~nm}(n=113)$ cells grown anaerobically with sulfate; $82 \pm 33 \mathrm{~nm}(n=258)$ in cells grown microaerobically with $\mathrm{O}_{2}$ ] (Supporting Information Fig. S4), with some being longer than $200 \mathrm{~nm}$ and present more defects in their morphologies (e.g., kinks) (Fig. 3). Fast Fourier transform (FFT) analysis performed on images obtained from high resolution transmission electron 


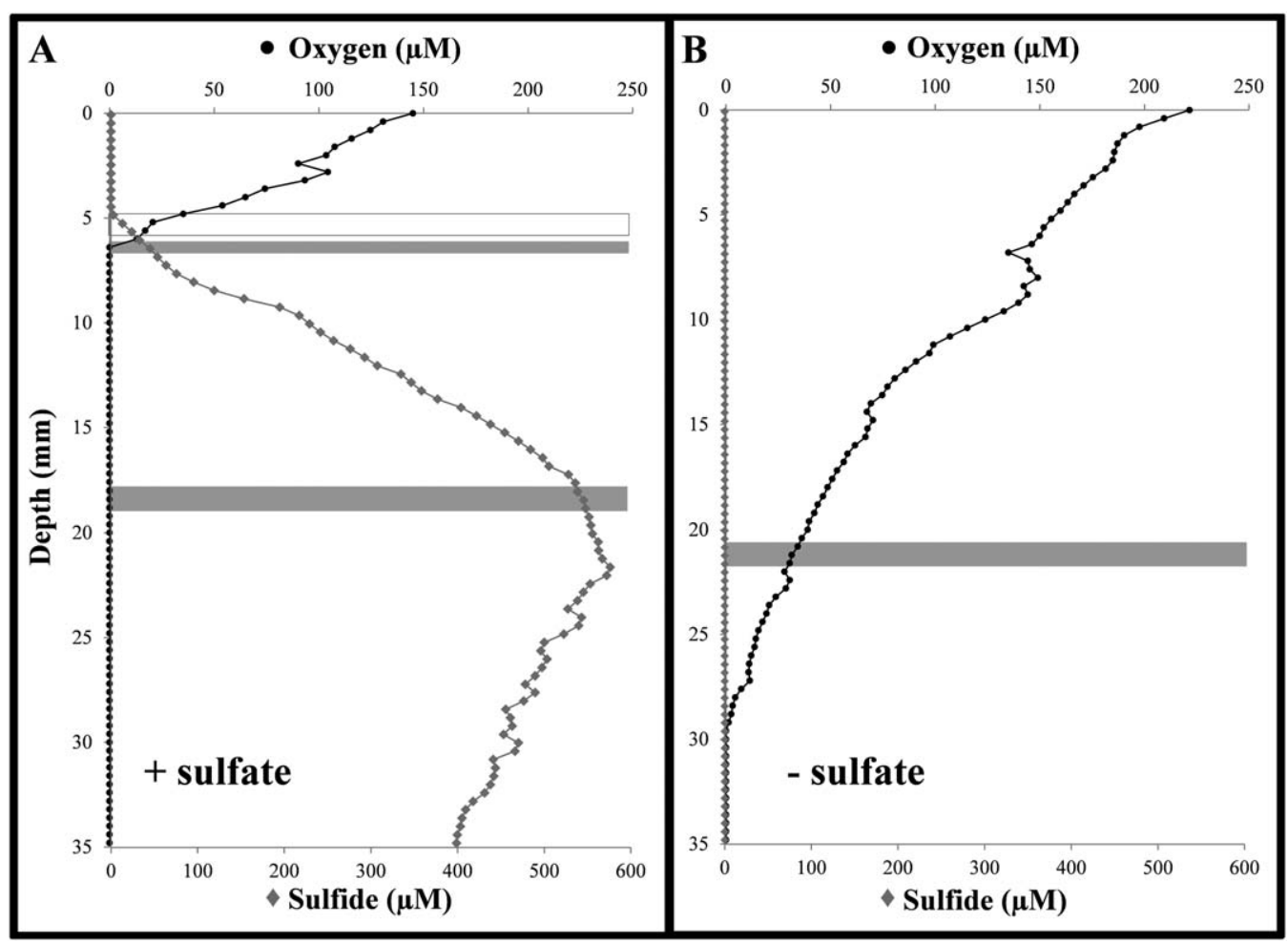

Fig. 2. Vertical concentration profiles of dissolved $\mathrm{O}_{2}(\bullet)$ and $\Sigma \mathrm{H}_{2} \mathrm{~S}+\mathrm{HS}^{-}(\bullet)$ through semi-solid $\left[\mathrm{O}_{2}\right]$-gradient cultures of Desulfovibrio magneticus strain RS-1. Profiles in the presence (A) or absence $(\mathbf{B})$ of sulfate in the culture medium. When sulfate is present in the culture (left profile), $\mathrm{H}_{2} \mathrm{~S}$ is produced through the reduction of sulfate by cells present in the anaerobic zone (band of cells represented by a grey band at $\sim 18 \mathrm{~mm}) . \mathrm{H}_{2} \mathrm{~S}$ diffuses upward toward the meniscus in the tube and leading to the formation of a layer of precipitate of sulfur $\left(\mathrm{S}^{0}\right)$ in the oxic, upper zone of the culture $\left(\mathrm{S}^{0}\right.$ represented by white band at $\sim 5 \mathrm{~mm}$ ). Although sulfate is present in the culture, a second band of cells formed at the oxic-anoxic interface (OAI) (band of cells represented by grey band at $\sim 6 \mathrm{~mm}$ ). When sulfate was omitted from the medium (right profile), no $\mathrm{H}_{2} \mathrm{~S}$ formed and cells grow as a single band (band of cells represented by a grey band at $\sim 21 \mathrm{~mm}$ ). In this latter tube, the optimal dissolved $\left[\mathrm{O}_{2}\right]$ for growth was approximately $28-31 \mu \mathrm{M}$. Profiles were obtained from cultures incubated 9 days after inoculation.

microscopy (HRTEM) show that the elongated magnetite crystals produced by RS- 1 grown microaerobically are single crystals (Fig. 3A). Although bright-field contrast variations on a highly curved magnetosome indicate two slightly misoriented sub-grains with a misorientation estimated at approximately $2^{\circ}$ (Fig. 3B), HRTEM and corresponding FFTs (Fig. 3 B2; B4) indicate that the two sub-grains are monocrystalline. Similar results were found for $D$. magneticus strain $\mathrm{FH}-1$ and $D$. putealis strain ZBP-1 (Supporting Information Fig. S5).

\section{In silico analysis of the mechanisms related to $\mathrm{O}_{2}$ reduction in desulfovibrio magneticus}

Several $\mathrm{O}_{2}$-reducing mechanisms have been characterized and studied in SRB, mostly from sequence data from the genome of $D$. vulgaris (Lamrabet et al., 2011). Genomic analysis of $D$. magneticus strain RS-1 (Nakazawa et al., 2009) shows that similar mechanisms are present in this species. Three gene clusters coding for oxidases, the enzyme known to be involved in reducing $\mathrm{O}_{2}$ to $\mathrm{H}_{2} \mathrm{O}$, are present in the genome sequence of strain
RS-1. Two of these clusters are cytochrome $b d$ ubiquinol oxidases (cydA: DMR_06960 and cydB: DMR_06970; cydA: DMR_28300 and cydB': DMR_28310) that share a maximum identity of sequence with orthologous genes from Desulfovibrio species (e.g., CydA has $78 \%$ identity of sequence with a cytochrome oxidase of $D$. fructosivorans and CydA' has $85 \%$ identity with a cytochrome $d$ ubiquinol oxidase subunit I of $D$. alcoholivorans). The third oxidase is a cytochrome $O$ ubiquinol oxidase composed by four subunits (DMR_14870 = cyoA", DMR_14880 = cyoB", DMR_14890 $=$ cyoC and DMR_14900 $=c y o D$ ) that shares a maximum sequence identity with orthologous genes from Desulfovibrio species (e.g., the subunit II has 66\% identity with the sequence of $D$. putealis).

Reactive oxygen species (superoxide, hydrogen peroxide and hydroxyl radical) are intermediates/products formed during $\mathrm{O}_{2}$ reduction (respiration). Their detoxification involves specific enzymes including superoxide dismutase, superoxide reductase and catalase, generally found in aerobic microorganisms in order to tolerate atmospheric concentrations of $\mathrm{O}_{2}$ during aerobic respiration. Genes for superoxide dismutase, encoded by the 


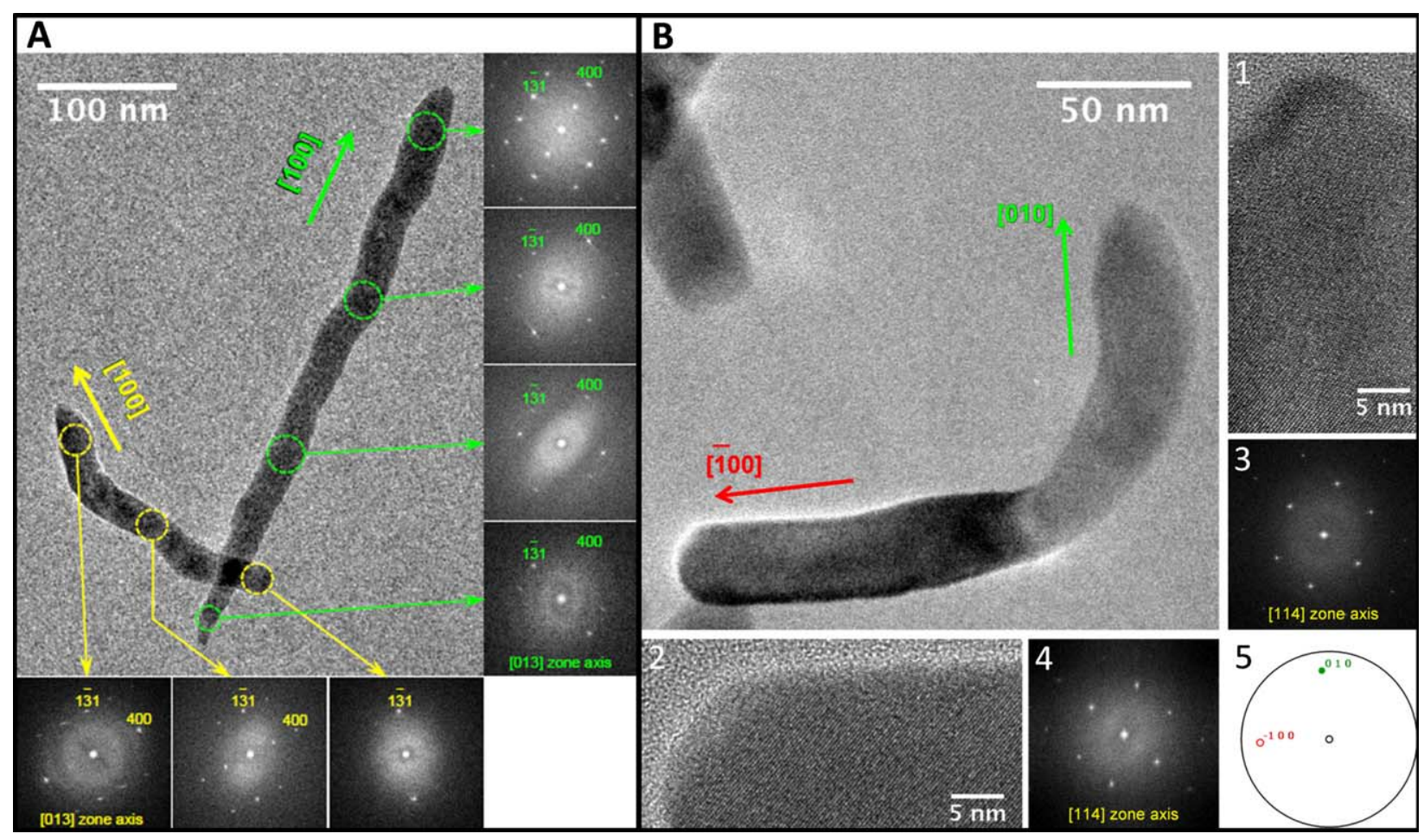

Fig. 3. Crystallographic properties of magnetite magnetosome crystals from cells of Desulfovibrio magneticus strain RS-1 grown microaerobically with $\mathrm{O}_{2}$ as the terminal electron acceptor. (A) Transmission electron microscope (TEM) image of elongated magnetosomes. High resolution TEM (HRTEM) images were obtained on whole crystals and fast Fourier transform (FFT) analysis performed on all HRTEM images. Each FFT is related to the selected area defined by the green or yellow dotted circles. FFTs from the same crystal have the same crystallographic orientation, that is, [013], showing that each magnetite particle is a single crystal. (B) TEM image (larger panel) of a highly curved magnetosome analyzed using bright-field contrast variations showing that the magnetosome is formed by two sub-grains slightly misoriented by approximately $2^{\circ}$. (B1 and B3) HRTEM and corresponding FFTs (B2 and B4) indicate that the two sub-grains are monocrystalline. The two elongation directions are respectively [010] and [100] as deduced from the stereographic projection analyses (B5).

sodB gene (DMR_42280), superoxide reductase, a rubredoxin oxidoreductase encoded by the rbo gene (DMR_17610) and catalase, encoded by the katA gene (DMR_34220), are all present in the genome of $D$. magneticus strain RS-1.

\section{Discussion}

Our finding that some SRB respire with $\mathrm{O}_{2}$ and link this reduction to growth explains many of the puzzling observations regarding these presumably strictly anaerobic organisms over many years. For example, Desulfovibrio species routinely exposed to relatively high concentration of $\mathrm{O}_{2}$ in natural environments such as microbial mats (Canfield and Des Marais, 1991; Krekeler et al., 1997; Teske et al., 1998) and biofilms (Ramsing et al., 1993) survive and may even be metabolically active under these conditions. Results presented here support this contention. The potential of Desulfovibrio species and other SRB to reduce and grow with $\mathrm{O}_{2}$ as a terminal electron acceptor demonstrates another, mostly unrecognized, important ecological role of these organisms.
Why reproducible growth of SRB with $\mathrm{O}_{2}$ as a terminal electron acceptor had not been demonstrated earlier despite a number of excellent studies focused on this question? Many anaerobes are known to not only require the absence of $\mathrm{O}_{2}$ for growth but specific redox conditions are also often required. Chemical reducing agents are often added to growth medium to facilitate the growth of many anaerobes not only by scavenging $\mathrm{O}_{2}$ but also to provide a suitable redox potential for growth. An excellent example of this is the methanogens. These organisms generally will not grow in medium simply where $\mathrm{O}_{2}$ has been eliminated and require the medium to have a very low redox potential obtained by the addition of a reducing agent such as $\mathrm{Na}_{2} \mathrm{~S}$ (Huber et al., 1982). The same requirement also applies to SRB where a low redox potential is also needed for optimal growth (Postgate, 1985). To obtain aerobic growth of SRB, a similar situation may apply, that is, for aerobic growth these organisms obviously require microaerobic conditions but perhaps a specific redox potential is also necessary. The $\left[\mathrm{O}_{2}\right]$-gradient medium used in this study provides both microaerobic conditions and an appropriate redox potential for growth. In our medium, 
cysteine and the relatively high concentration of $\mathrm{Fe}^{2+}$ in the medium (for magnetosome production) act as reducing agents. $\mathrm{O}_{2}$ in the headspace of the cultures diffuses into the culture resulting in the $\left[\mathrm{O}_{2}\right]$-gradient which is clearly observable when resazurin, a redox indicator (midpoint reduction potential Eo' $=380 \mathrm{mV}$ ), is added to the medium (oxic zone is pink while anoxic zone is colourless in the presence of resazurin). Moreover, in our semi-solid $\left[\mathrm{O}_{2}\right]$-gradient medium, cells can swim to their preferred $\left[\mathrm{O}_{2}\right]$ and redox potential. We believe that these specific conditions required for aerobic growth of SRB were not met in the growth media used in the numerous studies that failed to unequivocally demonstrate aerobic growth of SRB in the absence of sulfate (Ramel et al., 2015). It is also possible that the ability to respire $\mathrm{O}_{2}$ by some Desulfovibrio species was lost due to long term transfer in strictly anaerobic conditions and specific approaches such as experimental evolution would be required to obtain oxic growth.

Based on the apparent requirements for a specific $\left[\mathrm{O}_{2}\right]$ and redox potential for growth of the SRB used in our study, it is not surprising that cells grow as a microaerotactic band of cells in the $\left[\mathrm{O}_{2}\right]$-gradient medium when sulfate is omitted. However, when sulfate was present in the same medium, two bands of cells eventually formed, one migrating upward to the meniscus and the other downward to the anoxic zone of the gradient. Since the band that migrates downward forms secondarily to the original band (even if the medium is inoculated with cells grown anaerobically with sulfate), it is likely that the second band forms only when $\mathrm{O}_{2}$ becomes limiting by growing cells at the OAI. At this point, many cells in the original band at the OAI may start to switch their metabolism to the reduction of sulfate in the medium resulting in the formation of the second band. These cells eventually use up the sulfate at the band and then swim downward to obtain more sulfate. This result, in particular, suggests an important metabolic feature for the SRB used in this study, that is, the possibility that these SRB prefer to use $\mathrm{O}_{2}$ as a terminal electron acceptor to sulfate when conditions are appropriate. This explains the formation of the initial band at the OAI when sulfate is present in the growth medium. However, we cannot prove or disprove the possibility that both terminal electron acceptors are used by cells simultaneously in the original band although our results show no evidence of this in the form of $\mathrm{H}_{2} \mathrm{~S}$ production. Cells might have to reach a certain density in our cultures to initiate sulfate reduction under these conditions.

The $\mathrm{O}_{2}$ reduction rates for strain RS-1 $(128 \pm 27 \mathrm{nmol}$ of $\mathrm{O}_{2} \mathrm{~min}^{-1} \mathrm{mg}$ protein ${ }^{-1}$ ) and other Desulfovibrio species [e.g., D. vulgaris Marburg: $222 \mathrm{nmol}$ of $\mathrm{O}_{2} \mathrm{~min}^{-1} \mathrm{mg}$ protein $^{-1}$ (Baumgarten et al., 2001) and the highest $\mathrm{O}_{2}$ reduction rate reported for a SRB thus far, in $D$. termitidis:
$1570 \mathrm{nmol}$ of $\mathrm{O}_{2} \mathrm{~min}^{-1} \mathrm{mg}$ protein ${ }^{-1}$ (Kuhnigk et al., 1996)], are comparable to those of aerobic bacteria. The exact mechanism of $\mathrm{O}_{2}$ reduction by the $\mathrm{O}_{2}$-respiring Desulfovibrio species used in this study is not yet known although it certainly must involve some of the oxidases whose genes are present in the genome of $D$. magneticus. These include genes for cytochrome bd ubiquinol oxidases, cytochrome $d$ ubiquinol oxidase and cytochrome $O$ ubiquinol oxidase all of which are present in the genomes of other SRB (Dolla et al., 2006). Although the proton motive force generated by the activity of these enzymes appears to contribute at least partially to energy production in Desulfovibrio species (Lamrabet et al., 2011), additional studies are required to determine the functions of these oxidases in SRB as well as to elucidate the biochemical mechanism(s) involved in $\mathrm{O}_{2}$ reduction in these organisms.

A secondary important result of our study is the difference in the number of magnetosomes and the morphology of the magnetosome magnetite crystals produced by the magnetotactic SRB, D. magneticus strains RS-1 (Fig. 3) and FH-1 and D. putealis strain ZBP-1 (Supporting Information Fig. S5), under different growth conditions. These strains biomineralize more magnetosomes when grown aerobically than when grown anaerobically with sulfate. Sulfate-reducing cells of RS-1 were even once not considered to be an MTB (Pósfai et al., 2006). This is not the case with cells grown microaerobically which produce more magnetosomes per cell and larger magnetosome magnetite crystals than those grown with sulfate anaerobically. Moreover, the ability of magnetotactic SRB to respire with $\mathrm{O}_{2}$ and grow as a band at the OAl demonstrates that these organisms generally behave as other microaerophilic MTB using magnetotaxis to locate their optimal position at the OAI in $\left[\mathrm{O}_{2}\right]-$ gradients more efficiently (Bennet et al., 2014). The majority of cultured MTB are microaerophiles with some having alternative anaerobic metabolisms [e.g., respiration of $\mathrm{NO}_{3}^{-}$by Magnetospirillum species (Bazylinski and Blakemore, 1983) or $\mathrm{N}_{2} \mathrm{O}$ by Magnetovibrio blakemorei (Bazylinski et al., 1988)]. Only cultured MTB of the Deltaproteobacteria have been described as strict anaerobes, raising questions regarding the role of magnetosomes and the function of magnetotaxis in strictly anaerobic environments. It thus seems possible that all MTB have the potential to respire with $\mathrm{O}_{2}$ although the conditions to do so for some MTB only known to grow anaerobically remains to be elucidated.

Environmental conditions affect the composition, morphology and number of magnetosome crystals per cell, both in uncultured MTB in the environment and in cultured species (Bazylinski et al., 1995; Faivre et al., 2008). This also appears to be the case for $D$. magneticus. Magnetosome magnetite crystals appear to be 
involved in the elimination of reactive oxygen species in some MTB (Guo et al., 2012) and thus, especially considering the stringent conditions under which the magnetotactic Desulfovibrio strains grow microaerobically, might play a similar role in these organisms. Cells of $D$. magneticus strain RS-1, in microcapillary tubes containing an $\left[\mathrm{O}_{2}\right]$-gradient (Lefèvre et al., 2014), act like other microaerophilic MTB, that is, they swim back and forth along magnetic field lines through the band. However, they exhibit a unique behaviour, called unipolar magnetotaxis, when the magnetic field is reversed: all cells swim toward the anoxic zone. It was speculated that this behaviour was favourable to this species because the anoxic side is likely less toxic than the oxic side due to deleterious effects of exposure to high $\left[\mathrm{O}_{2}\right]$ (Lefèvre et al., 2014).

Bullet-shaped magnetosomes with a length greater than $200 \mathrm{~nm}$ were also reported in MTB from environmental samples such as the Moorsee in Bavaria (Vali and Kirschvink, 1991). MTB have great impacts on geology and paleomagnetism (Bazylinski and Moskowitz, 1997). When a magnetotactic bacterium dies and lyses, its magnetosome crystals are released into the surrounding environment where they can persist or undergo dissolution and/or transformation into other minerals. In habitats where the crystals persist over time, magnetotactic bacterial magnetite is an important, sometimes the primary, carrier of magnetic remanence in oceanic and lake sediments (Oldfield and Wu, 2000). Using isotopic dating and other technologies, investigators can determine when sediments were deposited which in turn provides important information about the origin and the evolution of MTB (Lefèvre et al., 2013). Magnetosomes are considered as indirect bacterial fossils, referred to as magnetofossils (Chang and Kirschvink, 1989). Thus, bullet-shaped particles with a length greater than $200 \mathrm{~nm}$ could represent suitable biomarkers of microoxic environments and thus could be used to infer the past environmental conditions in geological records containing such magnetofossils.

Our results pave the way to understanding the molecular mechanisms and metabolic pathways responsible for $\mathrm{O}_{2}$ respiration in SRB and the ecological roles these organisms play in biotopes where $\mathrm{O}_{2}$ is either temporarily or permanently present. Dissimilatory SRB have been dated back to 3.5 billion years ago, and along with the phototrophic iron oxidizing bacteria, are considered to be among the oldest microorganisms on Earth (Battistuzzi et al., 2004). Although speculative, our findings suggest that these organisms may have been the first prokaryotes to develop the ability to respire with $\mathrm{O}_{2}$ when microaerobic conditions developed and became common. Additional evidence for this could come from systematic examination of all SRB in both the Bacteria and the Archaea for the ability to respire and grow with $\mathrm{O}_{2}$ as the terminal electron acceptor, something that can now be done given the growth conditions that support aerobic growth of SRB described here.

\section{Experimental procedures}

Growth conditions, medium composition and isolation of magnetotactic strains

Cells of MTB from samples were concentrated using the magnetic "capillary racetrack" technique (Wolfe et al., $1987)$ and used as inocula in a modified semi-solid $\left[\mathrm{O}_{2}\right]-$ gradient enrichment medium similar to that described previously (Bazylinski et al., 2004). Modifications were that the basal medium contained (per liter): $5 \mathrm{ml}$ modified Wolfe's mineral elixir (Wolin et al., 1963; Bazylinski

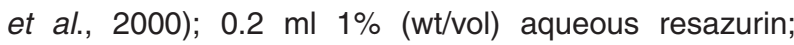
$0.25 \mathrm{~g} \mathrm{NH}_{4} \mathrm{Cl} ; 0.1 \mathrm{~g} \mathrm{MgSO}_{4} \cdot 7 \mathrm{H}_{2} \mathrm{O}$ and the $\mathrm{pH}$ adjusted to 7.0. $2.0 \mathrm{~g}$ of Bacto-Agar (Difco Laboratories, Detroit, $\mathrm{MI}$ ) was then added after which the medium was autoclaved. After autoclaving the following was added as sterile stock solutions (per liter): $0.5 \mathrm{ml}$ of vitamin solution (Frankel et al., 1997); of $0.5 \mathrm{M} \mathrm{KHPO}_{4}$ buffer $\mathrm{pH}$ $6.9 ; 2.67 \mathrm{ml}$ freshly made $0.8 \mathrm{M} \mathrm{NaHCO}_{3}$ (the $\mathrm{NaHCO}_{3}$ is autoclaved dry); $2.5 \mathrm{ml}$ of $10 \mathrm{mM}$ ferric quinate (Blakemore et al., 1979) and $0.4 \mathrm{~g}$ of freshly made neutralized filtered sterilized cysteine $\cdot \mathrm{HCl} \cdot 2 \mathrm{H}_{2} \mathrm{O}$. Screwcapped glass culture tubes were filled to approximately $60 \%$ of their volume with medium. The medium was allowed to sit at room temperature for several hours to solidify and to allow the $\left[\mathrm{O}_{2}\right]$-gradient to form as evidenced by the presence of a pink (oxidized) zone near the surface and a colourless (reduced) zone in the deeper portion of the tubes. Cultures were incubated at $25^{\circ} \mathrm{C}$. An axenic culture of strain $\mathrm{FH}-1$ was obtained from colonies by a shake tube technique while the axenic culture of strain ZBP-1 was obtained by dilution to extinction three times in succession in the semi-solid growth medium.

Cells of Desulfovibrio magneticus strain RS-1 (ATCC 700980; DSM 13731) and strains FH-1 and ZBP-1 were grown routinely in a semi-solid $\left[\mathrm{O}_{2}\right]$-gradient medium containing (per liter): $5 \mathrm{ml}$ modified sulfate-free Wolfe's mineral elixir (all sulfate salts were replaced with chlorides), $0.2 \mathrm{ml} 1 \%$ aqueous resazurin; $0.17 \mathrm{~g} \mathrm{NaNO}_{3}$ (used as nitrogen source only), $0.75 \mathrm{~g}$ sodium succinate $\cdot 6 \mathrm{H}_{2} \mathrm{O}$ and $0.082 \mathrm{~g} \mathrm{MgCl}_{2} \cdot 7 \mathrm{H}_{2} \mathrm{O}$ and the $\mathrm{pH}$ adjusted to 7.0. $1.0 \mathrm{~g}$ of Agarose (Difco Laboratories, Detroit, MI) was then added after which the medium was autoclaved. After autoclaving the following was added as sterile stock solutions (per liter): $0.5 \mathrm{ml}$ of vitamin solution; $2.8 \mathrm{ml}$ of $0.5 \mathrm{M} \mathrm{KHPO}_{4}$ buffer $\mathrm{pH}$ 7.0; $1.5 \mathrm{ml}$ of $0.8 \mathrm{M} \mathrm{NaHCO}_{3}$ solution; $3.5 \mathrm{ml}$ of $10 \mathrm{mM}$ $\mathrm{FeCl}_{2} \cdot 4 \mathrm{H}_{2} \mathrm{O}$ (in $0.02 \mathrm{~N} \mathrm{HCl}$ ); and $0.2 \mathrm{~g}$ of freshly made 
neutralized filtered sterilized cysteine $\cdot \mathrm{HCl} \cdot 2 \mathrm{H}_{2} \mathrm{O}$. Screw-capped glass culture tubes were filled to approximately $60 \%$ of their volume with medium. The medium was allowed to sit at room temperature for several hours to solidify and to allow the $\mathrm{O}_{2}$ concentration gradient to form as evidenced by the presence of a pink (oxidized) zone near the surface and a colourless (reduced) zone in the low part of the tubes.

The same medium with $0.75 \mathrm{~g}$ of sodium sulfate was used as a control allowing bacteria to grow anaerobically using sulfate as electron acceptor. Liquid anaerobic cultures were done in test tubes sparged with $\mathrm{O}_{2}$-free $\mathrm{N}_{2}$. The inhibition of sulfate reduction of strain RS-1 by molybdate was tested by the addition of increasing doses of sodium molybdate in the liquid anaerobic medium. At a concentration of $1 \mathrm{mM}$, sulfate reduction still occurred. Inhibition of sulfate reduction was observed at 2 and $3 \mathrm{mM}$ and the medium was clear. At $4 \mathrm{mM}$ molybdate, a brownish precipitate occurred in the medium and thus a concentration of $3 \mathrm{mM}$ was chosen as the concentration to inhibit sulfate reduction by strain RS-1.

\section{Chemical measurements}

A three microelectrode voltammetric cell was used to determine $\mathrm{O}_{2}$ and sulfide concentrations in semi-solid $\left[\mathrm{O}_{2}\right]$-gradient cultures (Brendel and Luther, 1995; Luther et al., 2008). Cells of strains RS-1 and FH-1 were grown in the same medium described above, in large test tubes to allow the electrodes to fit in the width of the tube. About $135 \mathrm{ml}$ of medium was added in these large test tubes. An $\mathrm{Ag} / \mathrm{AgCl}$ reference electrode and a Pt counter electrode were used in conjunction with an $\mathrm{Au} / \mathrm{Hg}$ working electrode. Preparation of the solid state $\mathrm{Au} / \mathrm{Hg}$ working microelectrode was performed as previously described (Brendel and Luther, 1995). Voltammetric measurements were made with an Analytical Instrument Systems DLK-100 analyzer (Analytical Instrument Systems, Inc., Flemington, $\mathrm{NJ}$ ) and recorded to computer. The microelectrode was controlled by a micromanipulator.

Sulfate concentrations in growth medium was determined using liquid chromatography on a highperformance liquid chromatography (HPLC) system consisting of a Shimadzu (Kyoto, Japan) model CBM-20A system controller, model LC-2OAD dual pumps, a CTO$20 \mathrm{AC}$ column oven and a CDD-10A VP detector. The system was linked to a computer containing the Shimadzu LCsolution system program which was used for analysis. A SeQuant Anion Supressor column [Shodex IC SI-90G (PEEK) $4.6 \times 10$, Phenomenex, Torrance, $\mathrm{CA}$ ] coupled with a CARS ${ }^{\mathrm{TM}}$ Continuous Anion Regeneration System was used to separate the sulfate. The mobile phase was composed of $\mathrm{NaHCO}_{3}(1 \mathrm{mM})$ and $\mathrm{Na}_{2} \mathrm{CO}_{3}(3.2 \mathrm{mM})(25: 75, \mathrm{v} / \mathrm{v})$ and was pumped at a flow rate of $1.5 \mathrm{ml} \mathrm{min}{ }^{-1}$. Standard concentration curves were made for sulfate with $r^{2}$ values greater than 0.99 .

Mass spectrometry measurements of $\mathrm{O}_{2}$ respiration

Cells were grown anaerobically with pyruvate and fumarate in liquid medium (Byrne et al., 2010) to an optical density $(O D)=1.1$ after which aliquots of the cells were placed in the measuring chamber $(1.5 \mathrm{ml})$ of a mass spectrometer (model PrimasB; Thermo Electron). The bottom of the chamber (Hansatech electrode type) was sealed by a Teflon membrane, allowing dissolved gases to be directly introduced through a vacuum line into the mass spectrometer ion source. The chamber was maintained at $30^{\circ} \mathrm{C}$, and the cell suspension stirred continuously magnetically. Air was then introduced into the suspension, reaching an $\left[\mathrm{O}_{2}\right]$ of $220 \mu \mathrm{M}$, before closing the chamber. $\mathrm{O}_{2}$ consumption was followed at $\mathrm{m} / \mathrm{e}=32$.

\section{Light and electron microscopy}

Images of the culture tubes were taken every $24 \mathrm{~h}$, less when necessary, in triplicate for each condition with a camera Nikon model D70 with the macro lens AF MICRO NIKKOR $60 \mathrm{~mm}$. The photographic chamber was black with a Fiber-L-Lite high-intensity illuminator series 180 (Dolan-Jenner Industries, Boxborough, MA) as only light source for optimal contrast and visualization of growth.

Light microscopy imaging was performed with a Zeiss Axiolmager M1 light microscope (Carl Zeiss Microlmaging, Inc., Thornwood, NY) equipped with phase-contrast and differential interference contrast capabilities. The hanging-drop technique (Schüler, 2002) was used routinely in the examination of MTB and to determine whether cells were magnetotactic.

Imaging and composition of the sulfur precipitate was preformed and determined by combinations of transmission electron microscopy (TEM), scanning-transmission electron microscopy (SEM) and energy-dispersive X-ray analysis (EDX) with a Tecnai (FEl Company, Hillsboro, OR) Model G2 F30 Super-Twin transmission electron microscope.

TEM of whole cells was done with a Tecnai (FEl Company, Hillsboro OR) model G2 F30 Super-Twin and G2 Biotwin and a JEOL (JEOL, Ltd., Tokyo, Japan) model 3010 transmission electron microscope. High-resolution TEM (HRTEM) and scanning transmission electron microscopy (STEM) were performed on whole cells and magnetosomes with a JEOL model 2100F (Field Emission Gun) operated at $200 \mathrm{kV}$ and equipped with a high resolution pole piece and a Gatan (Gatan, Inc., Pleasanton, CA) model US4000 (4k $\times 4 \mathrm{k})$ Charge-Couple Device (CCD) camera. Energy-dispersive X-ray (XEDS) elemental maps were acquired using energy-filtered 
TEM (EFTEM) with the JEOL $2100 \mathrm{~F}$ in the STEM darkfield mode with a focused electron beam (1 $\mathrm{nm}$ ). Selected-area electron diffraction (SAED) in the TEM was performed with the Tecnai and the JEOL model $2100 \mathrm{~F}$ electron microscopes.

\section{Determination of 16S rRNA gene sequence and phylogenetic analysis}

16S rRNA genes were amplified with Bacteria-specific primers 27F $5^{\prime}$-AGAGTTTGATCMTGGCTCAG- $3^{\prime}$ and 1492R 5'-TACGGHTACCTTGTTACGACTT-3' (Lane, 1991). PCR products were cloned into pGEM-T Easy Vector (Promega Corporation, Madison WI) and sequenced (Functional Biosciences, Inc., Madison WI).

Alignment of 16S rRNA genes was performed with CLUSTAL W multiple alignment accessory application in the BioEdit sequence alignment editor (Hall, 1999). Phylogenetic tree was constructed with MEGA version 5 (Tamura et al., 2011) applying the neighbour-joining method (Saitou and Nei, 1987). Bootstrap values were calculated with 1000 replicates.

\section{Nucleotide sequence accession numbers}

$16 \mathrm{~S}$ rRNA gene sequences of strains $\mathrm{FH}-1$ and ZBP-1 carry GenBank accession numbers JF330268 and JN015508 respectively.

\section{Acknowledgements}

We thank the HélioBiotec platform (funded by the European Union, the region Provence Alpes Côte d'Azur, the French Ministry of Research and the Commissariat à l'Energie Atomique et aux Energies Alternatives) for the mass spectrometer, and D. Pignol for helpful discussions and suggestions. This work was supported by U.S. National Science Foundation (NSF) grants EAR-0920718 and EAR-1423939. P.A.H. and M.L.S. were recipients of an award from the NSF Research Experience for Undergraduates (REU) program A Broad View of Environmental Microbiology at the University of Nevada at Las Vegas (Award NSF-0649267). C.T.L. was supported by the French National Research Agency (GROMA: ANR-14CE35-0018-01) and G.W.L. acknowledges support from U.S. National Aeronautics and Space Administration Exobiology Grant NNX12AG20G.

\section{References}

Abreu, F., Cantão, M.E., Nicolás, M.F., Barcellos, F.G., Morillo, V., Almeida, L.G. et al. (2011) Common ancestry of iron oxide- and iron-sulfide-based biomineralization in magnetotactic bacteria. Isme $J$ 5: 1634-1640.

Basso, O., Caumette, P., and Magot, M. (2005) Desulfovibrio putealis sp. nov., a novel sulfate-reducing bacterium isolated from a deep subsurface aquifer. Int $J$ Syst Evol Microbiol 55: 101-104.
Battersby, N.S., Malcolm, S.J., Brown, C.M., and Stanley, S.O. (1985) Sulphate reduction in oxic and sub-oxic North-East Atlantic sediments. FEMS Microbiol Lett 31: 225-228.

Battistuzzi, F.U., Feijao, A., and Hedges, S.B. (2004) A genomic timescale of prokaryote evolution: Insights into the origin of methanogenesis, phototrophy, and the colonization of land. BMC Evol Biol 4: 44.

Baumgarten, A., Redenius, I., Kranczoch, J., and Cypionka, H. (2001) Periplasmic oxygen reduction by Desulfovibrio species. Arch Microbiol 176: 306-309.

Bazylinski, D.A., and Blakemore, R.P. (1983) Denitrification and assimilatory nitrate reduction in Aquaspirillum magnetotacticum. Appl Environ Microbiol 46: 1118-1124.

Bazylinski, D.A., and Frankel, R.B. (2004) Magnetosome formation in prokaryotes. Nat Rev Microbiol 2: 217-230.

Bazylinski, D.A., and Moskowitz, B.M. (1997) Microbial biomineralization of magnetic iron minerals; microbiology, magnetism and environmental significance. Rev Miner Geochem 35: 181-223.

Bazylinski, D.A., Frankel, R.B., and Jannasch, H.W. (1988) Anaerobic magnetite production by a marine, magnetotactic bacterium. Nature 334: 518-519.

Bazylinski, D.A., Frankel, R.B., Heywood, B.R., Ahmadi, S., King, J.W., Donaghay, P.L., and Hanson, A.K. (1995) Controlled biomineralization of magnetite (Fe304) and greigite (Fe3S4). Appl Environ Microbiol 61: 3232-3239.

Bazylinski, D.A., Dean, A.J., Schüler, D., Phillips, E.J., and Lovley, D.R. (2000) $\mathrm{N}_{2}$-dependent growth and nitrogenase activity in the metal-metabolizing bacteria, Geobacter and Magnetospirillum species. Environ Microbiol 2: 266-273.

Bazylinski, D.A., Dean, A.J., Williams, T.J., Long, L.K., Middleton, S.L., and Dubbels, B.L. (2004) Chemolithoautotrophy in the marine, magnetotactic bacterial strains MV-1 and MV-2. Arch Microbiol 182: 373-387.

Bazylinski, D.A., Lefèvre, C.T., and Schüler, D. (2013) Magnetotactic bacteria. In The Prokaryotes. Rosenberg, E., DeLong, E.F., Lory, S., Stackebrandt, E., and Thompson, F. (eds.). Berlin Heidelberg: Springer, pp. 453-494.

Beijerinck, W.M. (1895) Uber Spirillum desulfuricans als ursache von sulfatreduction. Zentralb Bakteriol I/ 1: 104114.

Bennet, M., McCarthy, A., Fix, D., Edwards, M.R., Repp, F., Vach, P., et al. (2014) Influence of magnetic fields on magneto-aerotaxis. PLoS ONE 9: e101150.

Blakemore, R.P., Maratea, D., and Wolfe, R.S. (1979) Isolation and pure culture of a freshwater magnetic spirillum in chemically defined medium. J Bacteriol 140: 720-729.

Brendel, P.J., and Luther, G.W. (1995) Development of a gold amalgam voltammetric microelectrode for the determination of dissolved $\mathrm{Fe}, \mathrm{Mn}, \mathrm{O}_{2}$, and $\mathrm{S}(-\mathrm{II})$ in porewaters of marine and freshwater sediments. Environ Sci Technol 29: 751-761.

Byrne, M.E., Ball, D.A., Guerquin-Kern, J.L., Rouiller, I., Wu, T.D., Downing, K.H., et al. (2010) Desulfovibrio magneticus RS-1 contains an iron- and phosphorus-rich organelle distinct from its bullet-shaped magnetosomes. Proc Natl Acad Sci U S A 107: 12263-12268.

Canfield, D.E., and Des Marais, D.J. (1991) Aerobic sulfate reduction in microbial mats. Science 251: 1471-1473. 
Chang, S.B.R., and Kirschvink, J.L. (1989) Magnetofossils, the magnetization of sediments, and the evolution of magnetite biomineralization. Annu Rev Earth Planet Sci 17: 169-195.

Cypionka, H. (2000) Oxygen respiration by Desulfovibrio species. Annu Rev Microbiol 54: 827-848.

Cypionka, H., Widdel, F., and Pfennig, N. (1985) Survival of sulfate-reducing bacteria after oxygen stress, and growth in sulfate-free oxygen-sulfide gradients. FEMS Microbiol Lett 31: 39-45.

Dannenberg, S., Kroder, M., Dilling, W., and Cypionka, H. (1992) Oxidation of $\mathrm{H}_{2}$, organic compounds and inorganic sulfur compounds coupled to reduction of $\mathrm{O} 2$ or nitrate by sulfate reducing bacteria. Arch Microbiol 158: 93-99.

DeLong, E.F., Frankel, R.B., and Bazylinski, D.A. (1993) Multiple evolutionary origins of magnetotaxis in bacteria. Science 259: 803-806.

Devouard, B., Pósfai, M., Hua, X., Bazylinski, D.A., Frankel, R.B., and Buseck, P.R. (1998) Magnetite from magnetotactic bacteria: Size distributions and twinning. Am Miner 83: 1387-1398.

Dilling, W., and Cypionka, H. (1990) Aerobic respiration in sulfate-reducing bacteria. FEMS Microbiol Lett 71: 123127.

Dolla, A., Fournier, M., and Dermoun, Z. (2006) Oxygen defense in sulfate-reducing bacteria. $J$ Biotechnol 126: 87-100.

Faivre, D., Menguy, N., Pósfai, M., and Schüler, D. (2008) Environmental parameters affect the physical properties of fast-growing magnetosomes. Am Miner 93: 463-469.

Frankel, R.B., Bazylinski, D.A., Johnson, M.S., and Taylor, B.L. (1997) Magneto-aerotaxis in marine coccoid bacteria. Biophys J 73: 994-1000.

Guo, F.F., Yang, W., Jiang, W., Geng, S., Peng, T., and Li, J.L. (2012) Magnetosomes eliminate intracellular reactive oxygen species in Magnetospirillum gryphiswaldense MSR-1. Environ Microbiol 14: 1722-1729.

Hall, T. (1999) BioEdit: A user-friendly biological sequence alignment editor and analysis program for Windows 95/ 98/NT. Nucleic Acids Symp Ser 41: 95-98.

Hardy, J.A., and Hamilton, W.A. (1981) The oxygen tolerance of sulfate-reducing bacteria isolated from North Sea waters. Curr Microbiol 6: 259-262.

Huber, H., Thomm, M., König, H., Thies, G., and Stetter, K.O. (1982) Methanococcus thermolithotrophicus, a novel thermophilic lithotrophic methanogen. Arch Microbiol 132: 47-50.

Jogler, C., Wanner, G., Kolinko, S., Niebler, M., Amann, R., Petersen, N., et al. (2011) Conservation of proteobacterial magnetosome genes and structures in an uncultivated member of the deep-branching Nitrospira phylum. Proc Natl Acad Sci U S A 108: 1134-1139.

Johnson, M.S., Zhulin, I.G., Gapuzan, M.E.R., and Taylor, B.L. (1997) Oxygen-dependent growth of the obligate anaerobe Desulfovibrio vulgaris Hildenborough. J Bacteriol 179: 5598-5601.

Kolinko, S., Jogler, C., Katzmann, E., Wanner, G., Peplies, J., and Schüler, D. (2012) Single-cell analysis reveals a novel uncultivated magnetotactic bacterium within the candidate division OP3. Environ Microbiol 14: 1709-1721.
Krekeler, D., Sigalevich, P., Teske, A., Cypionka, H., and Cohen, Y. (1997) A sulfate-reducing bacterium from the oxic layer of a microbial mat from Solar Lake (Sinai), Desulfovibrio oxyclinae sp. nov. Arch Microbiol 167: 369375.

Kuhnigk, T., Branke, J., Krekeler, D., Cypionka, H., and Konig, H. (1996) A feasible role of sulfate-reducing bacteria in the termite gut. Syst Appl Microbiol 19: 139-149.

Lamrabet, O., Pieulle, L., Aubert, C., Mouhamar, F., Stocker, P., Dolla, A., and Brasseur, G. (2011) Oxygen reduction in the strict anaerobe Desulfovibrio vulgaris Hildenborough: Characterization of two membrane-bound oxygen reductases. Microbiol Read Engl 157: 27202732.

Lane, D.J. (1991) 16S/23S sequencing. In Nucleic Acid Techniques in Bacterial Systematics. Stackebrandt, E. and Goodfellow, M. (eds). New York: John Wiley \& Sons, pp. 115-175.

Lefèvre, C.T., and Bazylinski, D.A. (2013) Ecology, diversity, and evolution of magnetotactic bacteria. Microbiol Mol Biol Rev 77: 497-526.

Lefèvre, C.T., Menguy, N., Abreu, F., Lins, U., Pósfai, M., Prozorov, T., et al. (2011a) A cultured greigite-producing magnetotactic bacterium in a novel group of sulfatereducing bacteria. Science 334: 1720-1723.

Lefèvre, C.T., Pósfai, M., Abreu, F., Lins, U., Frankel, R.B., and Bazylinski, D.A. (2011b) Morphological features of elongated-anisotropic magnetosome crystals in magnetotactic bacteria of the Nitrospirae phylum and the Deltaproteobacteria class. Earth Planet Sci Lett 312: 194-200.

Lefèvre, C.T., Viloria, N., Schmidt, M.L., Pósfai, M., Frankel, R.B., and Bazylinski, D.A. (2012) Novel magnetiteproducing magnetotactic bacteria belonging to the Gammaproteobacteria. Isme J 6: 440-450.

Lefèvre, C.T., Trubitsyn, D., Abreu, F., Kolinko, S., de Almeida, L.G.P., de Vasconcelos, A.T.R., et al. (2013) Monophyletic origin of magnetotaxis and the first magnetosomes. Environ Microbiol 15: 2267-2274.

Lefèvre, C.T., Bennet, M., Landau, L., Vach, P., Pignol, D., Bazylinski, D.A., et al. (2014) Diversity of magnetoaerotactic behaviors and oxygen sensing mechanisms in cultured magnetotactic bacteria. Biophys J 107: 527-538.

Lin, W., and Pan, Y. (2015) A putative greigite-type magnetosome gene cluster from the candidate phylum Latescibacteria. Environ Microbiol Rep 7: 237-242.

Lobo, S.A.L., Melo, A.M.P., Carita, J.N., Teixeira, M., and Saraiva, L.M. (2007) The anaerobe Desulfovibrio desulfuricans ATCC 27774 grows at nearly atmospheric oxygen levels. FEBS Lett 581: 433-436.

Luther, G.W., Glazer, B.T., Ma, S., Trouwborst, R.E., Moore, T.S., Metzger, E., et al. (2008) Use of voltammetric solidstate (micro)electrodes for studying biogeochemical processes: Laboratory measurements to real time measurements with an in situ electrochemical analyzer (ISEA). Mar Chem 108: 221-235.

Nakazawa, H., Arakaki, A., Narita-Yamada, S., Yashiro, I., Jinno, K., Aoki, N., et al. (2009) Whole genome sequence of Desulfovibrio magneticus strain RS-1 revealed common gene clusters in magnetotactic bacteria. Genome Res 19: 1801-1808. 
Newport, P. J., and Nedwell, D.B. (1988) The mechanisms of inhibition of Desulfovibrio and Desulfotomaculum species by selenate and molybdate. J Appl Bacteriol 65: 419-423.

Oldfield, F., and Wu, R.J. (2000) The magnetic properties of the recent sediments of Brothers Water, NW England. $J$ Paleolimnol 23: 165-174.

Peck, H.D. (1959) The ATP dependent reduction of sulphate with hydrogen in extracts of Desulfovibrio desulfuricans. Proc Natl Acad Sci U S A 45: 701-708.

Pósfai, M., Moskowitz, B.M., Arató, B., Schüler, D., Flies, C., Bazylinski, D.A., and Frankel, R.B. (2006) Properties of intracellular magnetite crystals produced by Desulfovibrio magneticus strain RS-1. Earth Planet Sci Lett 249: 444-455.

Postgate, J.R. (1985) The Sulfate-Reducing Bacteria (2nd Edition) University Press, Cambridge. J Basic Microbiol 25: 202-202.

Rabus, R., Hansen, T.A., Widdel, F. (2013) Dissimilatory Sulfate- and Sulfur-Reducing Prokaryotes. In The Prokaryotes. Rosenberg, E., DeLong, E.F., Lory, S., Stackebrandt, E., and Thompson, F. (eds). Berlin Heidelberg: Springer, pp. 309-404.

Ramel, F., Brasseur, G., Pieulle, L., Valette, O., HirschlerRéa, A., Fardeau, M.L., and Dolla, A. (2015) Growth of the obligate anaerobe Desulfovibrio vulgaris Hildenborough under continuous low oxygen concentration sparging: Impact of the membrane-bound oxygen reductases. PloS One 10: e0123455.

Ramsing, N.B., Kühl, M., and Jørgensen, B.B. (1993) Distribution of sulfate-reducing bacteria, $\mathrm{O}_{2}$, and $\mathrm{H}_{2} \mathrm{~S}$ in photosynthetic biofilms determined by oligonucleotide probes and microelectrodes. Appl Environ Microbiol 59: 38403849.

Ranade, D.R., Dighe, A.S., Bhirangi, S.S., Panhalkar, V.S., and Yeole, T.Y. (1999) Evaluation of the use of sodium molybdate to inhibit sulphate reduction during anaerobic digestion of distillery waste. Bioresour Technol 68: 287291.

Rinke, C., Schwientek, P., Sczyrba, A., Ivanova, N.N., Anderson, I.J., Cheng, J.F., et al. (2013) Insights into the phylogeny and coding potential of microbial dark matter. Nature 499: 431-437.

Saitou, N., and Nei, M. (1987) The neighbor-joining method: A new method for reconstructing phylogenetic trees. Mol Biol Evol 4: 406-425.

Sakaguchi, T., Arakaki, A., and Matsunaga, T. (2002) Desulfovibrio magneticus sp nov., a novel sulfatereducing bacterium that produces intracellular singledomain-sized magnetite particles. Int J Syst Evol Microbiol 52: 215-221.

Sass, H., Cypionka, H., and Babenzien, H.D. (1996) Sulfate-reducing bacteria from the oxic sediment layers of the oligotrophic Lake Stechlin. Adv Limnol 48: 241-246.

Sass, H., Cypionka, H., and Babenzien, H.D. (1997) Vertical distribution of sulfate-reducing bacteria at the oxicanoxic interface in sediments of the oligotrophic Lake Stechlin. FEMS Microbiol Ecol 22: 245-255.

Sass, H., Berchtold, M., Branke, J., König, H., Cypionka, H., and Babenzien, H.D. (1998) Psychrotolerant sulfatereducing bacteria from an oxic freshwater sediment, description of Desulfovibrio cuneatus sp. nov. and Desulfovibrio litoralis sp. nov. Syst Appl Microbiol 21: 212-219.

Schüler, D. (2002) The biomineralization of magnetosomes in Magnetospirillum gryphiswaldense. Int Microbiol Off $J$ Span Soc Microbiol 5: 209-214.

Sigalevich, P., Meshorer, E., Helman, Y., and Cohen, Y. (2000) Transition from anaerobic to aerobic growth conditions for the sulfate-reducing bacterium Desulfovibrio oxyclinae results in flocculation. Appl Environ Microbiol 66: 5005-5012.

Storz, G., Tartaglia, L.A., Farr, S.B., and Ames, B.N. (1990) Bacterial defenses against oxidative stress. Trends Genet TIG 6: 363-368.

Tamura, K., Peterson, D., Peterson, N., Stecher, G., Nei, M., and Kumar, S. (2011) MEGA5: Molecular evolutionary genetics analysis using maximum likelihood, evolutionary distance, and maximum parsimony methods. Mol Biol Evol 28: 2731-2739.

Teske, A., Ramsing, N.B., Habicht, K., Fukui, M., Küver, J., Jørgensen, B.B., and Cohen, Y. (1998) Sulfate-reducing bacteria and their activities in cyanobacterial mats of solar lake (Sinai, Egypt). Appl Environ Microbiol 64: 2943-2951.

Vali, H., Kirschvink, J.L. (1991) Observations of magnetosome organization, surface structure, and iron biomineralization of undescribed magnetic bacteria: Evolutionary speculations. In Iron Biominerals. Frankel, R.B. and Blakemore, R.P. (eds). New York: Plenum Press, pp. 97-115.

Voordouw, G., and Wall, J.D. (1993) Genetics and molecular biology of sulfate-reducing bacteria. In Genetics and Molecular Biology of Anaerobic Bacteria, Brock/Springer Series in Contemporary Bioscience. Sebald, M. (ed). New York: Springer, pp. 456-473.

Wolfe, R.S., Thauer, R.K., and Pfennig, N. (1987) A "capillary racetrack" method for isolation of magnetotactic bacteria. FEMS Microbiol Lett 45: 31-35.

Wolin, E.A., Wolin, M.J., and Wolfe, R.S. (1963) Formation of methane by bacterial extracts. J Biol Chem 238: 28822886.

\section{Supporting Information}

Additional Supporting Information may be found in the online version of this article at the publisher's web-site:

Fig. S1. Phylogenetic tree, based on 16S rRNA gene sequences, showing the phylogenetic positions of Desulfovibrio magneticus strain RS-1, strain $\mathrm{FH}-1$ and strain ZBP-1, in the Deltaproteobacteria class of the Proteobacteria. Bootstrap values at nodes are percentages of 1000 replicates. Escherichia coli was used to root the tree. GenBank accession numbers are given in parentheses. Bar represents $2 \%$ sequence divergence.

Fig. S2. Light and electron microscope images and analysis of globular precipitates from a culture of Desulfovibrio magneticus strain RS-1 growing in a tube of $\left[\mathrm{O}_{2}\right]$-gradient medium containing $5.3 \mathrm{mM}$ sulfate. (A) and (B) light microscope images obtained using dark-field and differential interface contrast respectively. (C) scanning-transmission electron microscope (STEM) image showing a single globule on a copper grid. (D) elemental spectrum of a single globule (left) compared to that of background (right; area of grid without a 
globule present) using energy dispersive X-ray spectroscopy analysis showing that the globular precipitate is sulfur-rich and likely represents elemental sulfur $\left(\mathrm{S}^{0}\right)$. Other elements, for example, $\mathrm{Na}, \mathrm{K}$, are from the growth medium.

Fig. S3. $\mathrm{O}_{2}$ consumption by cell suspensions of Desulfovibrio magneticus strain RS-1 in growth medium. The cell suspensions had an optical density of 1.1 and were sparged with air until the dissolved $\mathrm{O}_{2}$ concentration was $220 \mu \mathrm{M}$, before closing the spectrometer chamber. The monitoring of $\mathrm{N}_{2}$ is a control showing that the correction of gas consumption from the mass spectrometer has properly been done, that is, there is no consumption of $\mathrm{N}_{2}$ by the cells.
Fig. S4. Comparison of magnetite crystal size in magnetosomes in cells of Desulfovibrio magneticus strain RS-1 grown in medium with (left panels) or without (right panels) sulfate. From top to bottom: plot of crystal width versus length; crystal length; crystal width; crystal shape factor distributions; and transmission electron microscope images of cells of strain RS-1.

Fig. S5. Magnetosome shapes of strains $\mathrm{FH}-1$ and ZBP-1 respiring oxygen. TEM images of cells of strain $\mathrm{FH}-1$ (A) and ZBP-1 (B) grown in semi-solid $\left[\mathrm{O}_{2}\right]$-gradient medium lacking sulfate showing defects in magnetosome magnetite morphologies. 